This item was submitted to Loughborough's Research Repository by the author.

Items in Figshare are protected by copyright, with all rights reserved, unless otherwise indicated.

\title{
Electrochromic and colorimetric properties of nickel(II) oxide thin films prepared by aerosol-assisted chemical vapor deposition
}

PLEASE CITE THE PUBLISHED VERSION

http://dx.doi.org/10.1021/am401025v

\section{PUBLISHER}

(C) American Chemical Society

VERSION

AM (Accepted Manuscript)

\section{LICENCE}

CC BY-NC-ND 4.0

\section{REPOSITORY RECORD}

Sialvi, Muhammad Z., Roger J. Mortimer, G.D. Wilcox, Mohd Mat-Teridi, Thomas S. Varley, K.G.U. Wijayantha, and Caroline A. Kirk. 2019. "Electrochromic and Colorimetric Properties of Nickel(ii) Oxide Thin Films Prepared by Aerosol-assisted Chemical Vapor Deposition". figshare. https://hdl.handle.net/2134/15413. 
This item was submitted to Loughborough's Institutional Repository (https://dspace.lboro.ac.uk/) by the author and is made available under the following Creative Commons Licence conditions.

\section{creative
commons}

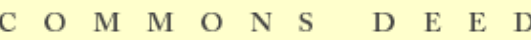

Attribution-NonCommercial-NoDerivs 2.5

You are free:

- to copy, distribute, display, and perform the work

Under the following conditions:

Attribution. You must attribute the work in the manner specified b the author or licensor.

Noncommercial. You may not use this work for commercial purposes.

No Derivative Works. You may not alter, transform, or build upon this work.

- For any reuse or distribution, you must make clear to others the license terms of this work.

- Any of these conditions can be waived if you get permission from the copyright holder.

Your fair use and other rights are in no way affected by the above.

This is a human-readable summary of the Leqal Code (the full license).

\section{Disclaimer 만}

For the full text of this licence, please go to: http://creativecommons.org/licenses/by-nc-nd/2.5/ 


\title{
Electrochromic and Colorimetric Properties of Nickel(II) Oxide Thin Films Prepared by Aerosol-Assisted Chemical Vapor Deposition
}

\author{
Muhammad Z. Sialvi, ${ }^{\dagger \ddagger}$ Roger J. Mortimer, ${ }^{\dagger *}$ Geoffrey D. Wilcox, ${ }^{\ddagger}$ Asri Mat Teridi, ${ }^{\dagger}$ Thomas S. \\ Varley, ${ }^{\#}$ K. G. Upul Wijayantha, ${ }^{\dagger}$ and Caroline A. Kirk ${ }^{\dagger}$ \\ ${ }^{\dagger}$ Department of Chemistry, Loughborough University, Loughborough, Leicestershire, LE11 3TU, UK \\ ${ }^{\ddagger}$ Department of Materials, Loughborough University, Loughborough, Leicestershire, LE11 3TU, UK \\ \#Department of Chemistry, University College London, 20 Gordon Street, London, $\mathrm{WC}_{1} \mathrm{H}$ oAJ, UK
}

\begin{abstract}
Aerosol-assisted chemical vapor deposition (AACVD) was used for the first time in the preparation of thinfilm electrochromic nickel(II) oxide (NiO). The as-deposited films were cubic $\mathrm{NiO}$, with an octahedral-like grain structure, and an optical band gap that decreased from 3.61 to $3.48 \mathrm{eV}$ on increase in film thickness (in the range 500-1000 $\mathrm{nm})$. On oxidative voltammetric cycling in aqueous $\mathrm{KOH}\left(0.1 \mathrm{~mol} \mathrm{dm}^{-3}\right)$ electrolyte the morphology gradually changed to an open porous $\mathrm{NiO}$ structure. The electrochromic properties of the films were investigated as a function of film thickness, following 50 , 100 and 500 conditioning oxidative voltammetric cycles in aqueous $\mathrm{KOH}\left(0.1 \mathrm{~mol} \mathrm{dm}^{-3}\right)$. Light modulation of the films increased with the number of conditioning cycles. The maximum coloration efficiency (CE) for the NiO (transmissive light green - the 'bleached' state) to $\mathrm{NiOOH}$ (deep brown - the colored state) electrochromic process was found to be $56.3 \mathrm{~cm}^{2} \mathrm{C}^{-1}$ (at $450 \mathrm{~nm}$ ) for films prepared by AACVD for $15 \mathrm{~min}$ followed by 100 'bleached'-to-colored conditioning oxidative voltammetric cycles. Electrochromic response times were $<10 \mathrm{~s}$ and generally longer for the coloration than the bleaching process. The films showed good stability when tested for up to $10000 \mathrm{color} / \mathrm{bleach}$ cycles. Using the CIE (Commission Internationale de l'Eclairage) system of colorimetry the color stimuli of the electrochromic NiO films and the changes that take place on reversibly oxidatively switching to the $\mathrm{NiOOH}$ form were calculated from in situ visible spectra recorded under electrochemical control. Reversible changes in the hue and saturation occur on oxidation of the $\mathrm{NiO}$ (transmissive light green) form to the $\mathrm{NiOOH}$ (deep brown) form, as shown by the track of the CIE 1931 xy chromaticity coordinates. As the $\mathrm{NiO}$ film is oxidized, a sharp decrease in luminance was observed. CIELAB $L^{*} a^{*} b^{*}$ coordinates were also used to quantify the electrochromic color states. A combination of a low $L^{*}$, positive $a^{*}$ and $b^{*}$ values, quantified the perceived deep brown colored state.
\end{abstract}

KEYWORDS: AACVD, nickel(II) oxide, electrochromic, electrochromism, CIE chromaticity coordinates, colorimetry

\section{INTRODUCTION}

Electrochromic materials have the property of a change, evocation, or bleaching of color, as effected by an applied electrical potential, sufficient to induce an electrochemical redox process. ${ }^{1,2}$ Applications of electrochromic materials include 'smart' windows for architectural applications, ${ }^{3}$ and anti-glare car mirrors, ${ }^{4}$ based on the modulation of transmitted and reflected visible radiation, respectively. The development of smart windows is the subject of intensive research, as implementation of such technology would lead to a significant reduction in energy consumption in highly glazed buildings by reducing cooling loads, heating loads and the demand for electric lighting, ${ }^{3}$ as well as improving indoor comfort due to less glare and thermal discomfort. ${ }^{5}$
Anodically-coloring thin-film nickel(II) oxide (NiO) is often used as a secondary electrochromic material to complement cathodically-coloring tungsten(VI) trioxide $\left(\mathrm{WO}_{3}\right)$ in prototype smart windows. ${ }^{6,7}$ Color switching properties of $\mathrm{NiO}$ (transmissive light green to deep brown), also make it potentially useful as a primary electrochromic material, where a 'neutral' colored state is desired. Electrochromic $\mathrm{NiO}$ thin films have been prepared by sputtering, ${ }^{8-10}$ electron-beam deposition, ${ }^{11}$ thermal evaporation, ${ }^{12}$ electrodeposition, ${ }^{13}$ template-assisted electrodeposition, ${ }^{14}$ sol-gel, ${ }^{15,16}$ chemical bath, ${ }^{17}$ hydrothermal deposition, ${ }^{18}$ chemical precipitation, ${ }^{19}$ hotfilament metal-oxide vapor deposition, ${ }^{20}$ and chemical vapor deposition $(\mathrm{CVD})^{21}$ techniques. We here report the first study of aerosol-assisted chemical vapor deposition (AACVD) of electrochromic $\mathrm{NiO}$ thin films and their characterization using powder X-ray diffraction (XRD), 
scanning electron microscopy (SEM) and optical absorption. As a variant of conventional CVD, AACVD involves the atomization of precursor solution into submicrometer-sized aerosol droplets. The droplets are then transported into a heating zone, where the solvent is rapidly evaporated, and the chemical precursors undergo decomposition and/or chemical reaction near or on a heated substrate to form the desired films. ${ }^{22}$ When compared to CVD, the AACVD method has several advantages. ${ }^{23-27}$ These include a wide choice and availability of precursor for depositing high quality coatings, the generation of aerosol to simplify the delivery and vaporization of precursor, and the ability to synthesize multicomponent products with precise stoichiometric control. Furthermore, low cost, high deposition rates and the ability to operate under varied environments at low pressure, or even in open atmosphere make AACVD an ideal process for scale up towards smart window applications.

The electrochromic properties of the NiO-based films prepared by AACVD are reported following transfer to aqueous $\mathrm{KOH}\left(0.1 \mathrm{~mol} \mathrm{dm}^{-3}\right)$ electrolyte, with colorimetric properties being quantified using CIE (Commission Internationale de l'Eclairage) principles. ${ }^{28}$ In colorimetry, the human eye's sensitivity to visible light is measured and a numerical description of the color stimulus is given, thus providing a more precise way to define color than qualitatively interpreting spectral absorption bands.

\section{EXPERIMENTAL SECTION}

Formation of NiO films by AACVD. Fluorine-doped tin oxide $\left(\mathrm{SnO}_{2}: \mathrm{F}, \mathrm{FTO}\right)$ on glass (Pilkington group limited, NSG TEC ${ }^{\mathrm{TM}} \mathrm{C}_{15}, R_{\mathrm{s}} 14 \Omega \square^{-1}$, light transmittance of $84 \%$ ) was used as the substrate for preparation of $\mathrm{NiO}$ films. To obtain uniform adherent films the FTO/glass substrates (each cut to $50 \mathrm{x} 7 \mathrm{~mm}$ dimensions) were cleaned by rinsing in deionized water, followed by sonication for 10 minutes each in deionized water, propan-2ol, acetone and ethanol. Prior to AACVD, the top $20 \mathrm{~mm}$ of each FTO/glass substrate was masked with glass, such that the $\mathrm{NiO}$ would deposit on the lower $30 \times 7 \mathrm{~mm}$ area.

Figure 1 shows a schematic diagram of the two chamber configuration AACVD apparatus. Each FTO/glass substrate was heated to $450{ }^{\circ} \mathrm{C}$ on a temperature controlled hot plate. For preparation of the $\mathrm{NiO}$ films, nickel(II) acetylacetonate $\left(0.05 \mathrm{~mol} \mathrm{dm}^{-3}\right)$ was used as the source material. Precursor solution was prepared by heating and stirring nickel(II) acetylacetonate and $1 \mathrm{~cm}^{3}$ of $N, N$ dimethylaminoethanol (used to improve the solubility of the nickel(II) complex and to enhance volatility) in toluene for 30 min then allowing the solution to cool to room temperature. The precursor solution was then placed above the piezoelectric modulator of an ultrasonic humidifier to atomize the solution into fine aerosol droplets. Using air as a carrier gas, the aerosol droplets were first transferred at a flow rate of $0.21 \mathrm{dm}^{3} \mathrm{~min}^{-1}$ into the first chamber where any large particles were separated and held. A second carrier gas (air) at a flow rate of $2.34 \mathrm{dm}^{3}$ $\min ^{-1}$ was then used to direct the small particles towards the heated substrate, where they underwent evaporation, decomposition and chemical reaction to synthesize the desired films. The flow rate was controlled by a LiX linear flow meter. Films were deposited for 10,15 and 20 minutes and are here abbreviated as $\mathrm{NiO}(10 \mathrm{~min}), \mathrm{NiO}(15$ min) and $\mathrm{NiO}$ (20 min) respectively.

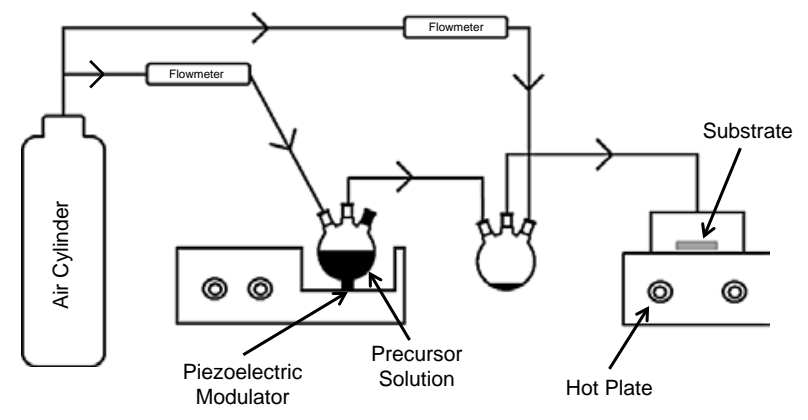

Figure 1. Schematic diagram of the experimental AACVD apparatus

XRD and SEM characterization. Powder XRD data were collected on a Bruker Advance D8 powder X-ray diffractometer in reflection geometry using $\mathrm{Cu} \mathrm{K} \alpha_{1}$ radiation with a Ge monochromator and linear position sensitive detector (PSD) over the two theta range $5-65^{\circ} 2 \Theta$ with a step size of $0.014^{\circ} 2 \Theta$ and a total collection time of 4 hours. Films deposited onto FTO/glass substrates were mounted on perspex sample holders. Shifts in the reflection positions were observed as no internal standard could be added to the sample for calibration of the reflection positions.

A Leo 1530 field emission gun scanning electron microscopy (SEM) system was used to examine the film morphologies. The deposited films were washed with distilled water, dried in air and then mounted on SEM stubs using conducting silver paint. Samples were coated with a thin layer of gold to improve the conductivity of the films. A Polaron Emitech $\mathrm{SC}_{7} 6 \mathrm{o}_{4}$ sputter coater was used.

Electrochemical, spectroelectrochemical and color measurement. A Princeton Applied Research 263A potentiostat was used for electrode potential control. $\mathrm{NiO} / \mathrm{FTO} /$ glass substrates (with adhesive copper tape at the top for uniform electrical contact), platinized titanium and a saturated calomel $\left(\mathrm{Hg} / \mathrm{Hg}_{2} \mathrm{Cl}_{2}\right)$ electrode (SCE) were used as working, counter and reference electrodes, respectively. A single compartment electrochemical cell was used for all measurements.

In situ visible region spectra were recorded in transmission mode using a Hewlett Packard 8452A diode array spectrophotometer. A standard $1 \mathrm{~cm}$ path length polystyrene cuvette was used as the spectroelectrochemical cell, with a machined polytetrafluoroethylene lid that allowed each $\mathrm{NiO} / \mathrm{FTO} /$ glass substrate to be placed parallel to the optical faces. In this case, a silver wire acted as a pseudo 
reference electrode, with a platinized titanium counter electrode. CIE 1931 xy chromaticity coordinates and luminance data were calculated from the spectral absorbance-wavelength data as described earlier. ${ }^{29}$ For simulation of mid-morning to mid-afternoon natural light, the relative power distribution of a $\mathrm{D}_{55}$ constant temperature (5500 K black body radiation) standard illuminant was used in the calculations. Chromaticity coordinates were also transformed to $L^{*} a^{*} b^{*}$ coordinates, a uniform color space (CIELAB) defined by the CIE in $1976 .^{30}$

\section{RESULTS AND DISCUSSION}

Crystalline phases identified, film morphology and optical absorption of the as-deposited $\mathrm{NiO}$ films. Figure 2 shows the powder XRD patterns for $\mathrm{NiO}$ films on FTO/glass at different deposition times. The reflections at $37.3^{\circ}, 43.3^{\circ}$ and $62.9^{\circ} 2 \Theta$ can be assigned to cubic $\mathrm{NiO}$ (International Centre for Diffraction Data (ICDD) Powder Diffraction File (PDF) 47-1049). The NiO phase is stable and its formation is independent of the film thickness. The intensity of the $\mathrm{NiO}$ reflections suggests preferred orientation of the films, as the (111) reflection is more intense than the (200). In a randomly oriented sample of $\mathrm{NiO}$, the (200) reflection should be the most intense.

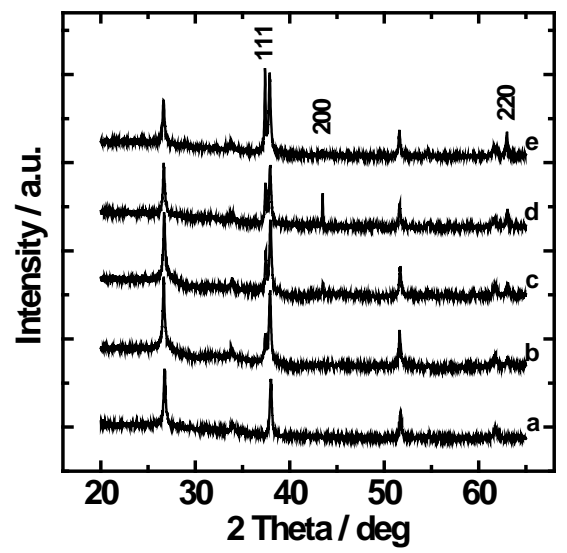

Figure 2. Powder XRD patterns for: (a) FTO/glass, (b) $\mathrm{NiO}(10 \mathrm{~min})$, (c) $\mathrm{NiO}(15 \mathrm{~min})$, (d) $\mathrm{NiO}(20 \mathrm{~min})$ and (e) $\mathrm{NiO}(20 \mathrm{~min})$ after 3500 oxidative conditioning voltammetric cycles in aqueous $\mathrm{KOH}\left(0.1 \mathrm{~mol} \mathrm{dm}^{-3}\right)$.

Figure 3 includes photographs for the as-deposited $\mathrm{NiO}$ films at the three deposition times, with SEM images shown in Figure 4. Uniform $\mathrm{NiO}$ film covers the FTO/glass substrate surface and exhibits a nano-scale morphology of octahedral-like grains. EDS analysis (Figures $S_{1}$ and S2, Supporting Information) shows no evidence of the presence of nitrogen from the decomposition of the dimethylaminoethanol. The cross-sectional images (inserts in Figure 4) show that film thickness increases with deposition time.
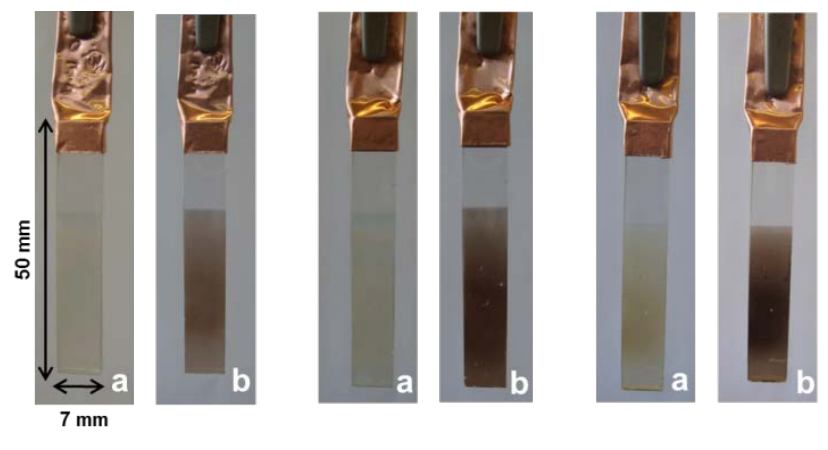

$\mathrm{NiO}(10 \mathrm{~min})$

$\mathrm{NiO}(15 \mathrm{~min})$

$\mathrm{NiO}(20 \mathrm{~min})$

Figure 3. Photographs of (a) as deposited $\mathrm{NiO}$ films and (b) $\mathrm{NiOOH}$ films (following 3500 cycles -0.50 to $+0.70 \mathrm{~V}$ vs. SCE at $50 \mathrm{mV} \mathrm{s}^{-1}$, and then removal at $+0.70 \mathrm{~V}$ ). Each film was deposited on the lower $30 \mathrm{~mm}$ length of each $7 \mathrm{~mm}$ width FTO/glass).
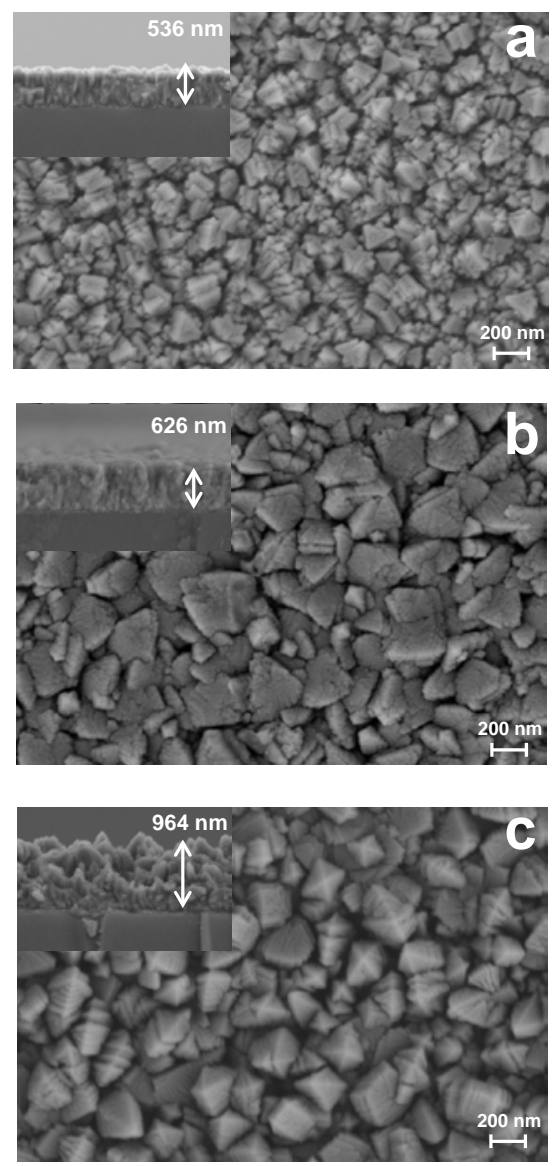

Figure 4. SEM images of $\mathrm{NiO}$ films deposited on FTO/glass for three deposition times: (a) $\mathrm{NiO}$ (1o min), (b) $\mathrm{NiO}(15 \mathrm{~min}$ ) and (c) $\mathrm{NiO}(20 \mathrm{~min})$. Inserts illustrate the cross sectional images. 
Figure $S_{3}$ in the Supporting Information shows the optical absorption spectra for the as-deposited films record-

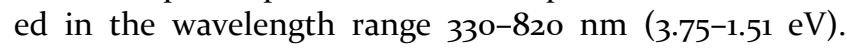
The data were analyzed using a classical relation for near edge optical absorption in semiconductor materials. ${ }^{31}$ Analyzing the variation of $(\alpha h v)^{2}$ vs. photon energy $(h v)$ in $\mathrm{eV}$ for $\mathrm{NiO}$ films suggests a direct interband transition. The band gaps were $3.61,3.53$ and $3.48 \mathrm{eV}$ for the $\mathrm{NiO}$ (10 min), $\mathrm{NiO}(15 \mathrm{~min})$ and $\mathrm{NiO}(20 \mathrm{~min})$ films, respectively. These direct band energy values are in good agreement with literature values for $\mathrm{NiO}$ thin films prepared by spray pyrolysis using aqueous nickel chloride solutions, with the slight decrease in band gap with increasing film thickness being attributed to increased grain size. ${ }^{32}$

Transformation of $\mathrm{NiO}$ morphology on voltammetric cycling in aqueous $\mathrm{KOH}\left(0.1 \mathrm{~mol} \mathrm{dm}^{-3}\right)$ electrolyte. Figure 5 shows an example of cyclic voltammograms

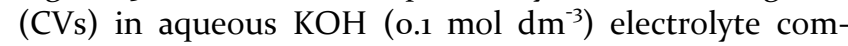
mencing with, in this case, an as-deposited $\mathrm{NiO}(15 \mathrm{~min})$ film. From the plot it can be seen that during the first 50 cycles, a continuous increase in capacity under the oxidation and reduction process takes place. This process is known as the so called activation period and has been reported for $\mathrm{NiO}$ films prepared by sol-gel, ${ }^{33}$ and pulsed laser-deposition. ${ }^{34-36}$ Furthermore, due to this activation process, on continuous oxidative voltammetric cycling, the octahedral-like grains of as-deposited $\mathrm{NiO}$ (Figure 6 (a)), gradually transform to an open porous structure of interconnected flakes (see Figure 6 (b), following 3500 voltammetric cycles and Figure $\mathrm{S}_{4}$ (Supporting Information), for a $\mathrm{NiO}(20 \mathrm{~min})$ film following 500 voltammetric cycles). Such a porous interconnecting structure will enhance the intercalation/deintercalation of hydroxide ions (Equation (1), a simplified form of the redox process) during voltammetric cycling, thus leading to enhanced electrochromic performance. Similar porous morphologies have been previously reported for NiO-based films prepared by chemical bath deposition methods. ${ }^{17,37}$

$\mathrm{NiO}+\mathrm{OH}^{-} \rightleftharpoons \mathrm{NiOOH}+\mathrm{e}^{-}$

The electrochemically generated porous $\mathrm{NiO}$ is electrochromic and oxidatively switches (Equation (1)) from a 'bleached' (transmissive light green) state to the colored nickel oxyhydroxide (NiOOH) (deep brown - for photographs see Figure 3) state. On continuous cycling, this process of morphology transformation is enhanced as the peak currents gradually increase with cycle number (Figure 5).

The two broad redox peaks in the CVs (Figure 5) are associated with the coloration and bleaching process for $\mathrm{NiO},{ }^{38}$ one anodic peak $\left(\mathrm{A}_{1}\right)$, responsible for the oxidation and one cathodic peak $\left(A_{2}\right)$, for the reduction process. For all sets of such CVs, an increase in anodic current after +o.6o V (B) is observed which corresponds to the beginning of the oxygen evolution reaction (OER). These $\mathrm{CV}$ features are similar to those obtained for $\mathrm{NiO}$ thin films initially prepared by electrodeposition ${ }^{13}$ and chemi- cal bath deposition ${ }^{39}$ techniques. The anodic and cathodic peak currents increase (Figure 7) with an increase in deposition time, with more electroactive material being available. XRD data collected on this sample showed $\mathrm{NiO}$ still to be present (Figure $2(\mathrm{e})$ ), but the relative intensities were now different to the original deposited film, with the (20o) reflection especially reduced in intensity. This agrees with the morphology changes shown in the SEM images (Figure 6).

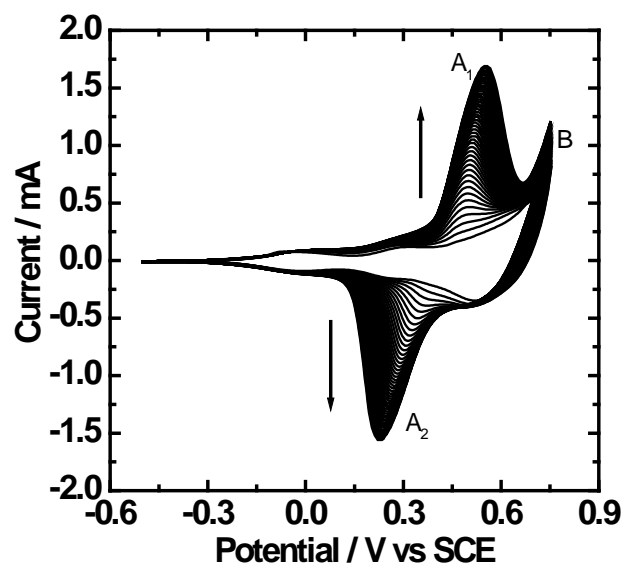

Figure 5. CVs starting from the as-deposited $\mathrm{NiO}(15 \mathrm{~min})$ film in aqueous $\mathrm{KOH}\left(0.1 \mathrm{~mol} \mathrm{dm}^{-3}\right)$. The potential range was $-0.50 \mathrm{~V} \rightarrow+0.70 \mathrm{~V} \rightarrow-0.50 \mathrm{~V}$ vs. SCE for 50 cycles at the scan rate of $50 \mathrm{mV} \mathrm{s}^{-1}$.
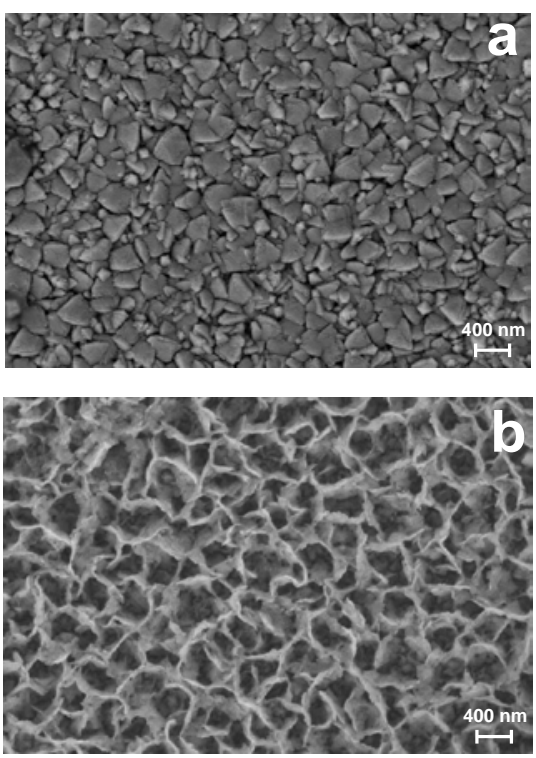

Figure 6. SEM images of $\mathrm{NiO}(15 \mathrm{~min})$ films deposited on FTO/glass: (a) as-deposited and (b) following 3500 voltammetric cycles in aqueous $\mathrm{KOH}\left(\mathrm{o} .1 \mathrm{~mol} \mathrm{dm}^{-3}\right)$. 


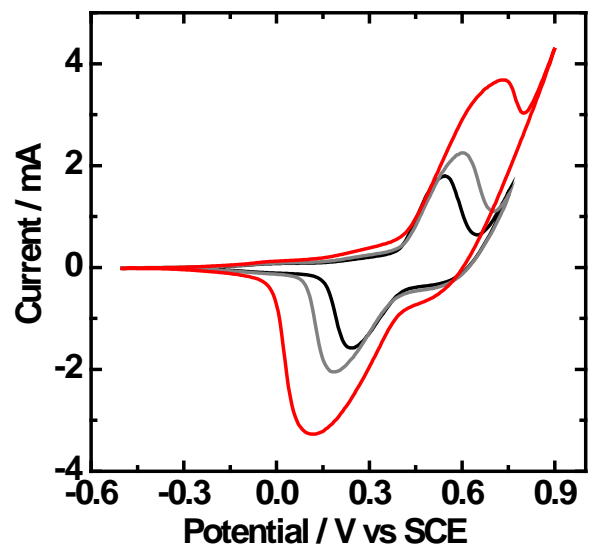

Figure 7. The 1ooth $\mathrm{CV}$ (at $50 \mathrm{mV} \mathrm{s}^{-1}$ ) in aqueous $\mathrm{KOH}$ (o.1 mol $\mathrm{dm}^{-3}$ ) of films prepared from as-deposited $\mathrm{NiO}(10 \mathrm{~min})$ $(\longrightarrow), \mathrm{NiO}(15 \mathrm{~min})(\longrightarrow)$ and $\mathrm{NiO}(20 \mathrm{~min})(\longrightarrow$.

Electrochromic properties. Table 1 gives in situ spectral data and calculated electrochromic performance parameters for square-wave potential switching between the 'bleached' and colored forms after the as-deposited $\mathrm{NiO}$ films (prepared by AACVD for 10, 15 and 20 minutes) had been subject to 50,100 and 500 continuous conditioning oxidative voltammetric cycles in aqueous $\mathrm{KOH}$ (o.1 mol $\mathrm{dm}^{-3}$ ) electrolyte. Figure 8 shows example visible region in situ transmittance spectra, in this case for the asdeposited $\mathrm{NiO}(15 \mathrm{~min})$ film, and in the oxidized $\mathrm{NiOOH}$ colored state, following increasing numbers of conditioning cycles. For such a film, it is noted from Table 1 , that after 500 cycles the change in optical transmittance between the 'bleached' and colored forms increased from $21.4 \%$ to $54.8 \%$ when measured at $550 \mathrm{~nm}$. This increase in transmittance change between the 'bleached' and colored state on continuous cycling is once again due to the gradual change in film morphology from octahedral-like grains to a high surface area of porous interconnecting flakes. Such porous morphology shows greater electrochromic performance due to increased contact between active material and electrolyte for facilitating hydroxide ion penetration.

Figure 9 shows the transmittance spectra of all the asdeposited $\mathrm{NiO}$ films in the 'bleached' and colored states. Transmittances for both the 'bleached' $\left(T_{\mathrm{b}}\right)$ and colored $\left(T_{\mathrm{c}}\right)$ states decrease as the deposition time increases (Table 1 and Figure 9). On increase of deposition time the extent of color change to the oxidized form increases but the films also appear less transparent in the reduced state (for photographs see Figure 3). The films deposited for 10, 15 and $20 \mathrm{~min}$, followed by 500 voltammetric cycles, each present the largest contrast (Table 1), the transmittance change $(-54 \%$ at $550 \mathrm{~nm})$ between the 'bleached' and colored states, being more than that of the films that were conditioned by only 50 and 100 cycles.
Table 1. In situ spectral data and electrochromic performance parameters on square wave switching (o.oo $\mathrm{V} \rightarrow+0.50 \mathrm{~V} \rightarrow-0.20 \mathrm{~V}$ vs. silver wire) between the 'bleached' and colored states after the as-deposited $\mathrm{NiO}$ films had been subject to 50,100 , and 500 continuous conditioning oxidative voltammetric cycles in aqueous $\mathrm{KOH}\left(0.1 \mathrm{~mol} \mathrm{dm}^{-3}\right)^{a}$

\begin{tabular}{llllllll}
\hline $\begin{array}{l}\text { original film } \\
\text { source }\end{array}$ & $\begin{array}{l}\text { cycle } \\
\text { no. }\end{array}$ & $\% T_{b}$ & $\% T_{c}$ & $\Delta \% T$ & $\Delta A$ & $\begin{array}{c}\mathrm{CE} / \\
\mathrm{cm}^{2} \mathrm{C}^{-1}\end{array}$ & $\begin{array}{l}t_{\mathrm{c}} / \mathrm{t}_{\mathrm{b}} \\
(\mathrm{s})\end{array}$ \\
\hline $\mathrm{NiO}(10 \mathrm{~min})$ & 50 & 86.8 & 66.6 & 20.0 & 0.11 & 39.6 & $3.2 / 2.7$ \\
$\mathrm{NiO}(10 \mathrm{~min})$ & 100 & 85.6 & 55.4 & 30.2 & 0.19 & 40.3 & $3.4 / 2.9$ \\
$\mathrm{NiO}(10 \mathrm{~min})$ & 500 & 84.6 & 30.9 & 53.7 & 0.44 & 34.6 & $5.6 / 3.8$ \\
$\mathrm{NiO}(15 \mathrm{~min})$ & 50 & 75.3 & 53.9 & 21.4 & 0.15 & 43.2 & $3.2 / 2.8$ \\
$\mathrm{NiO}(15 \mathrm{~min})$ & 100 & 74.8 & 46.4 & 28.4 & 0.21 & 45.0 & $4.1 / 3.6$ \\
$\mathrm{NiO}(15 \mathrm{~min})$ & 500 & 74.4 & 19.6 & 54.8 & 0.58 & 39.8 & $5.7 / 5.6$ \\
$\mathrm{NiO}(20 \mathrm{~min})$ & 50 & 65.9 & 33.7 & 32.2 & 0.30 & 41.8 & $5.0 / 4.2$ \\
$\mathrm{NiO}(20 \mathrm{~min})$ & 100 & 65.5 & 24.0 & 41.5 & 0.44 & 41.8 & $5.0 / 4.2$ \\
$\mathrm{NiO}(20 \mathrm{~min})$ & 500 & 66.3 & 12.5 & 53.8 & 0.72 & 32.5 & $7.4 / 6.5$ \\
\hline
\end{tabular}

${ }^{a} T_{\mathrm{b}}=$ transmittance of 'bleached' form, $T_{\mathrm{c}}=$ transmittance of colored form, $\Delta \% T$ = change in transmittance between the 'bleached' and colored forms, $\Delta A=$ change in absorbance, $\mathrm{CE}$ $=$ coloration efficiency, $t_{\mathrm{c}}$ and $t_{\mathrm{b}}=$ switching times for coloration and bleaching. All measurements were taken at the wavelength for maximal absorbance change, $550 \mathrm{~nm}$, which is also the wavelength where the human eye is most sensitive.

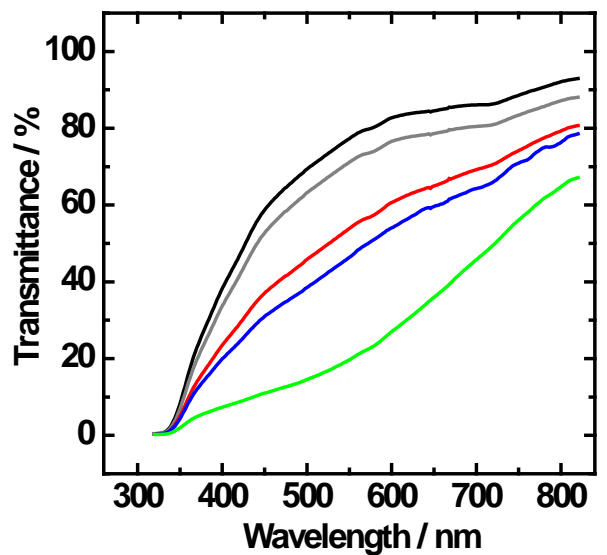

Figure 8. Visible region in situ transmission spectra recorded in the wavelength range $320-820 \mathrm{~nm}$ in aqueous $\mathrm{KOH}$ (o.1 mol $\mathrm{dm}^{-3}$ ), showing the formation of the colored state with conditioning oxidative voltammetric cycle number. Asdeposited $\mathrm{NiO}(15 \mathrm{~min})$ film at o.oo V vs. silver wire (—). As-deposited $\mathrm{NiO}(15 \mathrm{~min})$ film at $+0.40 \mathrm{~V}$ vs. silver wire ( -$)$. $\mathrm{NiO}(15 \mathrm{~min})$ film at $+0.40 \mathrm{~V}$ vs. silver wire, following 50 voltammetric cycles $-0.50 \mathrm{~V} \rightarrow+0.70 \mathrm{~V} \rightarrow-0.50 \mathrm{~V}$ vs. $\mathrm{SCE}(\longrightarrow$. $\mathrm{NiO}(15 \mathrm{~min})$ film at $+0.40 \mathrm{~V}$ vs. silver wire, following 100 voltammetric cycles $-0.50 \mathrm{~V} \rightarrow+0.70 \mathrm{~V} \rightarrow-0.50$ $\mathrm{V}(\longrightarrow)$. $\mathrm{NiO}(15)$ film at $+0.60 \mathrm{~V}$ vs. silver wire, following 500 voltammetric cycles $-0.50 \mathrm{~V} \rightarrow+0.70 \mathrm{~V} \rightarrow-0.50 \mathrm{~V}$ $(-$ All spectra were corrected for the transmittance 
of the uncoated FTO/glass substrate in aqueous $\mathrm{KOH}$ (o.1 mol dm ${ }^{-3}$ ).

Spectral data were further used to calculate the electrical power consumption of each electrochromic film, expressed as the coloration efficiency $(\mathrm{CE}=(\Delta A) \lambda / \mathrm{nm} / Q)$, where $(\Delta A)$ is the absorbance change between the 'bleached' and colored states and $Q$ is the charge density $\left(\mathrm{mC} \mathrm{cm}^{-2}\right)$ for each switching process. Each charge density was calculated by integration of the current-time transients, recorded on switching color states. Examples of current-time transients (Figure $\mathrm{S}_{5}$, Supporting Information) and visible region absorbance spectra (Figure 10) are given for the reversible switching between the 'bleached' and colored states of one of the films. On oxidation of the transmissive green 'bleached' state, the visible region absorbance increases (Figure 1o (a)) as the deep brown colored state forms. On reduction, the deep brown colored state reverts to the transmissive green 'bleached' state, with a decrease in the visible region absorbance (Figure $10(\mathrm{~b})$ ). The absorbance change, $\Delta A$, increases with increasing deposition time and the number of 'bleached'/colored cycles (Table 1). The highest values (o.72 at $550 \mathrm{~nm}$ (Figure 11 and Table 1) and o.88 at $450 \mathrm{~nm}$ (Figure 11)) were obtained for $\mathrm{NiO}(20 \mathrm{~min})$ recorded at 500 cycles. The CE values (Table 1 and Figure 12) are comparable to those for films obtained by electrodeposition $\left(50 \mathrm{~cm}^{2} \mathrm{C}^{-1}\right),{ }^{13}$ template-assisted electrodeposition (41 $\left.\mathrm{cm}^{2} \mathrm{C}^{-1}\right),{ }^{14} \mathrm{CVD}\left(44 \mathrm{~cm}^{2} \mathrm{C}^{-1}\right),{ }^{21}$ spray pyrolysis $\left(30 \mathrm{~cm}^{2} \mathrm{C}^{-1}\right)^{40}$ and vacuum evaporation $\left(32 \mathrm{~cm}^{2} \mathrm{C}^{-1}\right) .^{41}$

Absorbance vs. time plots (not included) were used to calculate the response times (Table 1 ) for all the $\mathrm{NiO}$ thin films. Response time is defined as the time required for obtaining partial or total change in absorbance ${ }^{1}$. Here, response times are reported as the time taken for the absorbance to reach $90 \%$ of the total absorbance change for both coloration $\left(t_{\mathrm{c}}\right)$ and 'bleaching' $\left(t_{\mathrm{b}}\right)$ process (Table 1 ). Response times for both coloration and 'bleaching' increased with both increasing number of conditioning cycles and film thickness. Generally, response times for the coloration process were longer than those for the 'bleaching' process.

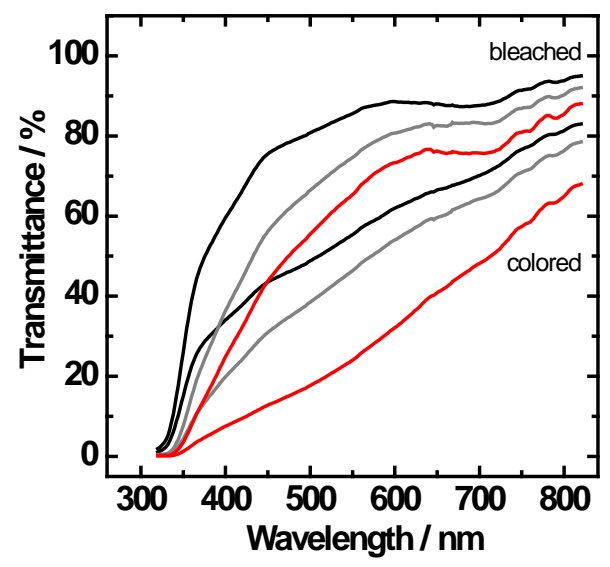

Figure 9. Visible region in situ transmission spectra for the 'bleached' and colored states following 100 voltammetric cycles in aqueous $\mathrm{KOH}\left(0.1 \mathrm{~mol} \mathrm{dm}^{-3}\right)$ : $\mathrm{NiO}(10 \mathrm{~min})(-)$, $\mathrm{NiO}(15 \mathrm{~min})(-)$ and $\mathrm{NiO}(20 \mathrm{~min})(-)$. For each, the upper spectrum is that for the 'bleached' form.
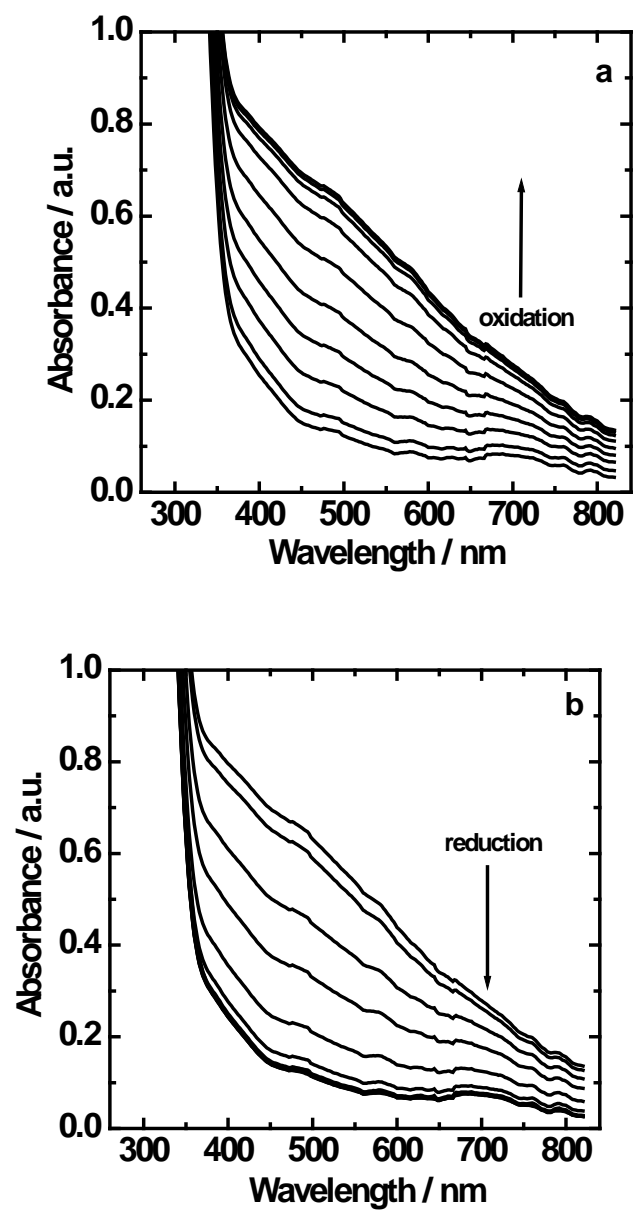

Figure 10. Visible region absorbance spectra ((a) and (b), spectra recorded every $0.5 \mathrm{~s})$, for the reversible switching of a $\mathrm{NiO}(10 \mathrm{~min})$ film in aqueous $\mathrm{KOH}\left(0.1 \mathrm{~mol} \mathrm{dm}^{-3}\right)$ between the transmissive green 'bleached' state and the colored (deep brown) state. Electrochromic switching was conducted by application of potential steps $(0.00 \mathrm{~V} \rightarrow+0.50 \mathrm{~V} \rightarrow-0.20 \mathrm{~V})$ vs. silver wire. The arrows indicate the direction of change in absorbance. The $\mathrm{NiO}(10 \mathrm{~min})$ film had first been conditioned by 500 cycles $(-0.50 \rightarrow+0.70 \rightarrow-0.50 \mathrm{~V}$ vs. SCE $)$ at 50 $\mathrm{mV} \mathrm{s}^{-1}$. 


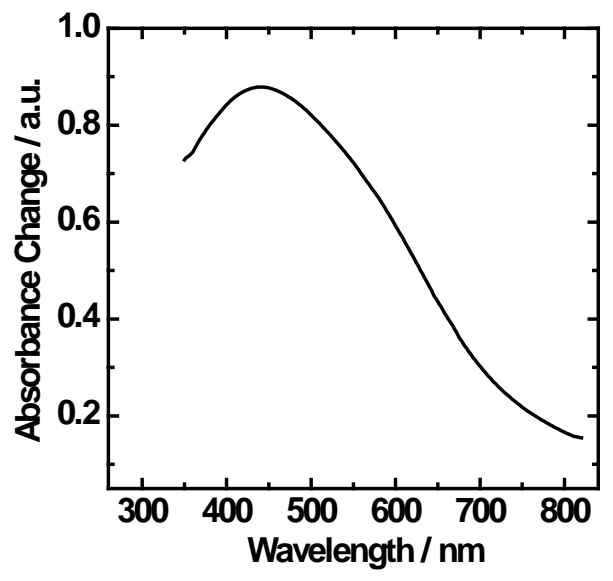

Figure 11. Change in absorbance of $\mathrm{NiO}(20 \mathrm{~min})$ film recorded at cycle 500 in the wavelength range of $350-820 \mathrm{~nm}$.

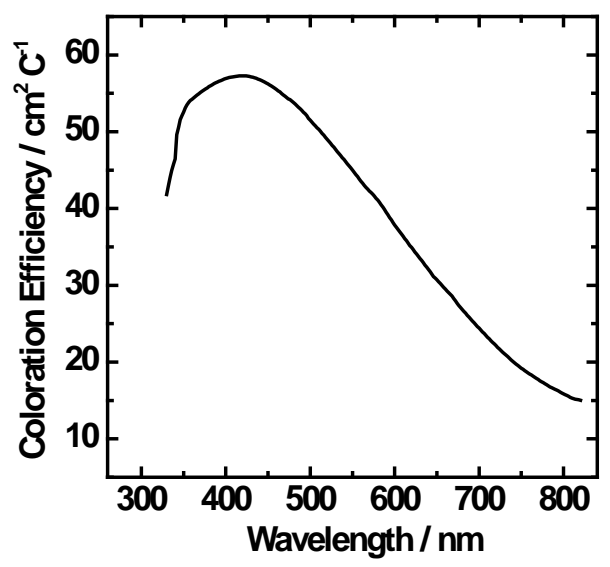

Figure 12. Coloration efficiency of $\mathrm{NiO}(15 \mathrm{~min})$ film recorded at cycle 100 in the wavelength range of $330-820 \mathrm{~nm}$.

Cycle life is one of the key parameters for commercialization as it is an experimental measure of the film durability. Figure 13 shows the visible in situ transmittance spectra of the as-deposited $\mathrm{NiO}$ (10 $\mathrm{min}$ ) film following the $1000^{\text {th }}$ and $10000^{\text {th }}$ cycles. At $550 \mathrm{~nm}$, the transmittance of the 'bleached' state was $93.5 \%$ and $88.7 \%$ respectively, after the $1000^{\text {th }}$ and $10000^{\text {th }}$ cycles. The transmittance of the 'colored' state was $49.3 \%$ and $47.6 \%$ respectively, after the $1000^{\text {th }}$ and $10000^{\text {th }}$ cycles. The change in transmittance between the $1000^{\text {th }}(\Delta \% T=44.2 \%)$ and $10000^{\text {th }}$ $(\Delta \% T=41.1 \%)$ cycle was minimal, indicating good adherence of the film and consistent color-switching properties. This shows that the NiO film deposited by AACVD is stable and suitable for electrochromic window applications. By way of comparison, in our laboratory we have prepared $\mathrm{NiO}$ films by electrodeposition and on electrochromic switching we found the change in transmittance, $\Delta \% T$, to decrease from 84.8 to $56.0 \%$, after just 50 electrochromic cycles.

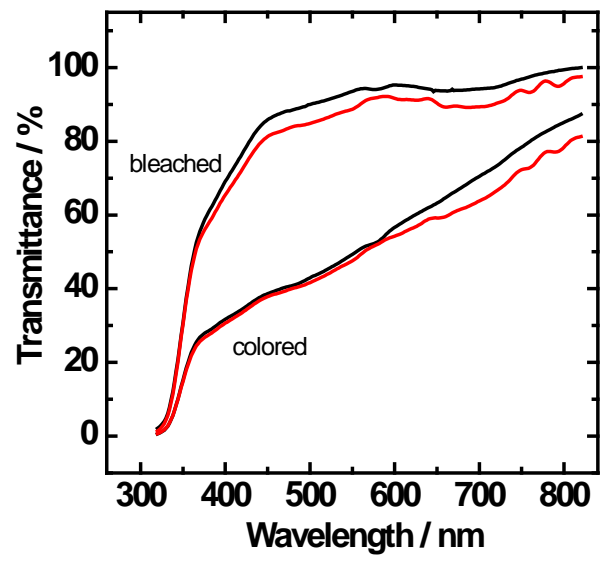

Figure 13. Visible region in situ transmission spectra for a $\mathrm{NiO}(10 \mathrm{~min})$ film following the $1000^{\text {th }}(\longrightarrow)$ and $10000^{\text {th }}$ (-) CV in the 'bleached' and colored states recorded in the wavelength range of $320-820 \mathrm{~nm}$ in aqueous $\mathrm{KOH}$ (o.1 $\left.\mathrm{mol} \mathrm{dm}^{-3}\right)$. The film had been cycled for 1000 and $10000 \mathrm{cy}-$ cles $(-0.50 \rightarrow+0.70 \rightarrow-0.50 \mathrm{~V}$ vs. SCE $)$ at $50 \mathrm{mV} \mathrm{s}^{-1}$.

Color measurement of the NiO-based thin films. Table 2 gives CIE $1931 \% Y_{L} x y$ and CIELAB $L^{*} a^{*} b^{*}$ chromaticity coordinates for the various films as calculated from visible region absorbance spectra (such as Figure 10 (a) and (b)).

Table 2. Chromaticity coordinates (CIE $1931 \% Y_{L} x y$ and CIELAB $L^{*} a^{*} b^{*}$ ) for each of the $\mathrm{NiO} / \mathrm{NiOOH}$ films on FTO/glass ${ }^{\mathrm{a}}$

\begin{tabular}{lllllll}
\hline $\begin{array}{l}\text { original film } \\
\text { source }\end{array}$ & $x$ & $y$ & $\% Y_{L}$ & $L^{*}$ & $a^{*}$ & $b^{*}$ \\
\hline $\begin{array}{l}\text { NiO(10 min) } \\
\text { 'bleached' }\end{array}$ & 0.347 & 0.362 & 86.7 & 95 & 0 & 8 \\
$\begin{array}{l}\text { NiO(10 min) } \\
\text { colored }\end{array}$ & $\mathbf{0 . 3 9 2}$ & 0.377 & 32.3 & 64 & 10 & 17 \\
$\begin{array}{l}\text { NiO(15 min) } \\
\text { 'bleached' }\end{array}$ & 0.361 & 0.376 & 77.1 & 90 & 1 & 16 \\
$\begin{array}{l}\text { NiO(15 min) } \\
\text { colored }\end{array}$ & $\mathbf{0 . 4 2 0}$ & 0.391 & 21.3 & 53 & 12 & 23 \\
$\begin{array}{l}\text { NiO(20 min) } \\
\text { 'bleached' }\end{array}$ & 0.374 & 0.386 & 69.5 & 87 & 2 & 21 \\
$\begin{array}{l}\text { NiO(2o min) } \\
\text { colored }\end{array}$ & $\mathbf{0 . 4 4 7}$ & 0.397 & 13.9 & 44 & 15 & 25 \\
\hline
\end{tabular}

${ }^{a}$ Films were switched in aqueous $\mathrm{KOH}\left(0.1 \mathrm{~mol} \mathrm{dm}^{-3}\right)$ between the 'bleached' and colored states by application of potential steps $(0.00 \mathrm{~V} \rightarrow+0.50 \mathrm{~V}$ for $10 \mathrm{~s}$ and $+0.50 \mathrm{~V} \rightarrow-$ $0.20 \mathrm{~V}$ for $10 \mathrm{~s}$ ) vs. silver wire.

Figure 14 (a) shows the dynamic changes of the CIE 1931 $x y$ coordinates as a hue and saturation track, on potential 
stepping between the 'bleached' and colored states, as a function of the deposition time of the original $\mathrm{NiO}$ films.
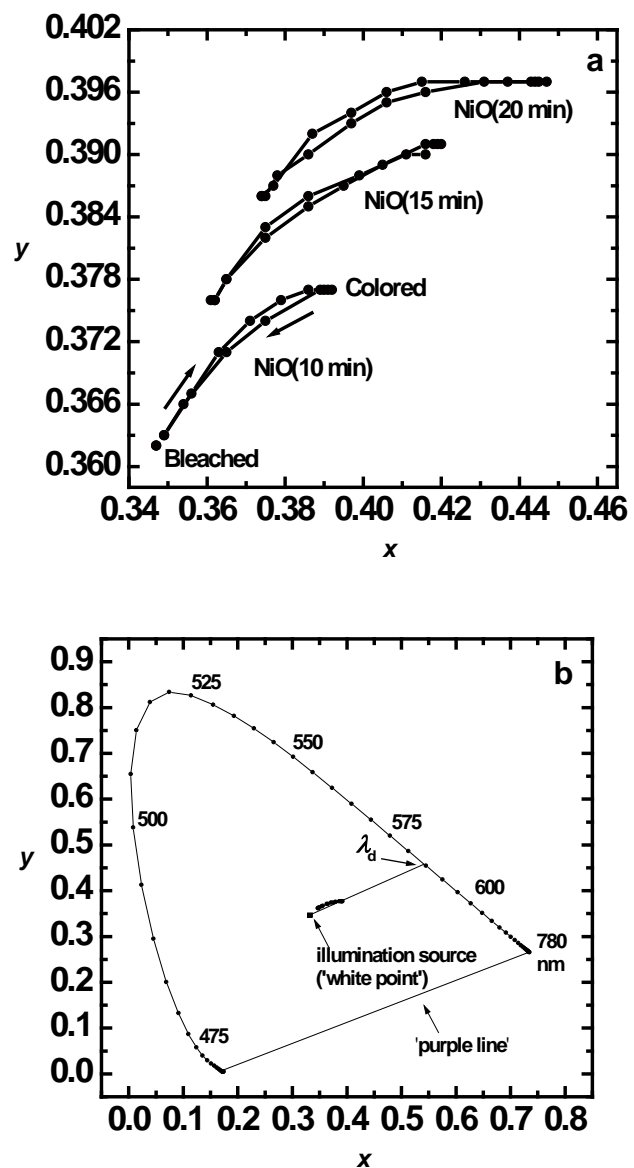

Figure 14. (a) CIE 1931 xy chromaticity plots for each of the $\mathrm{NiO} / \mathrm{NiOOH}$ films on FTO/glass. Films were switched in aqueous $\mathrm{KOH}\left(0.1 \mathrm{~mol} \mathrm{dm}^{-3}\right)$ between the 'bleached' and colored states by application of potential steps (o.oo $\mathrm{V} \rightarrow+0.50$ $\mathrm{V}$ for $10 \mathrm{~s}$ and $+0.50 \mathrm{~V} \rightarrow-0.20 \mathrm{~V}$ for $10 \mathrm{~s}$ ) vs. silver wire. The arrows indicate the direction of the changes with the potential. (b) CIE 1931 xy coordinates for the $\mathrm{NiO} / \mathrm{NiOOH}$ film on FTO/glass prepared from the as-deposited $\mathrm{NiO}$ (10 min). This Figure shows the locus coordinates, with labeled hue wavelengths, and the evaluation of the dominant wavelength $\left(\lambda_{d}=\right.$ $584 \mathrm{~nm})$ ) of the deep brown state.

At the initial applied potential (o.oo V), the 'bleached' films appear by eye as transmissive light green. With an increase in film thickness, the $x, y$ and $\% Y_{\mathrm{L}}$ coordinates (Table 2) depart from those of the illumination source (the 'white point', where $x=0.332, y=0.347$, and $\% Y_{L}=$ 100), as the light green color becomes slightly more intense. On stepping the applied potential to $+0.50 \mathrm{~V}$, films steadily turn to deep brown, with an increase in the $x$ and $y$ coordinates, and decrease in the luminance $\left(\% Y_{\mathrm{L}}\right)$ (Table 2 and Figure $14(\mathrm{a})$ ). In Figure 14 (b), the $x y$ data for films prepared from as-deposited $\mathrm{NiO}(10 \mathrm{~min})$ are over- laid onto the CIE 1931 color space template, showing the track of the $x y$ coordinates between the 'bleached' and colored states. In this representation, the line surrounding the horse-shoe shaped area is called the spectral locus, giving the visible light wavelength. The most saturated colors lie along the spectral locus. The line connecting the longest and shortest wavelength contains the non-spectral purples and is known as the purple line. Surrounded by the spectral locus and the purple line is the region known as the color locus, which contains every color that can exist. The location of any point in the $x y$ diagram gives the hue and saturation of the color. The hue may be determined by drawing a straight line from the white point, through the point of interest to the spectral locus, thus obtaining the dominant wavelength $\left(\lambda_{d}\right)$. The construction in Figure 14 (b) gives an estimated value of $584 \mathrm{~nm}$ for colored (deep brown) state of the film prepared from as-deposited $\mathrm{NiO}(10 \mathrm{~min})$. There is a small increase in $\lambda_{d}$ values with increase in deposition time, with values being 585 and $587 \mathrm{~nm}$ for films prepared from $\mathrm{NiO}(15 \mathrm{~min})$ and $\mathrm{NiO}(20 \mathrm{~min})$, respectively.

In CIE theory, colors cannot be specifically associated with a given pair of $x y$ coordinates, because the third dimension of color, lightness, is not included in the diagram. The relative lightness or darkness of a color is very important in how it is perceived, and is presented as the relative or percentage luminance, $Y_{L}$, of the sample, to that of the background, $Y_{o}$. Relative luminance values can range from $100 \%$ for white/transparent samples (no light absorbed) to zero for samples that absorb all the light. Figure 15 shows the graphical form of the changes in the $\% Y_{L}$ on potential switching between the 'bleached' and colored state for all the $\mathrm{NiO}$-based films. When the films are oxidized, the luminance dramatically decreases, as the deep brown color forms and steadily becomes more saturated.

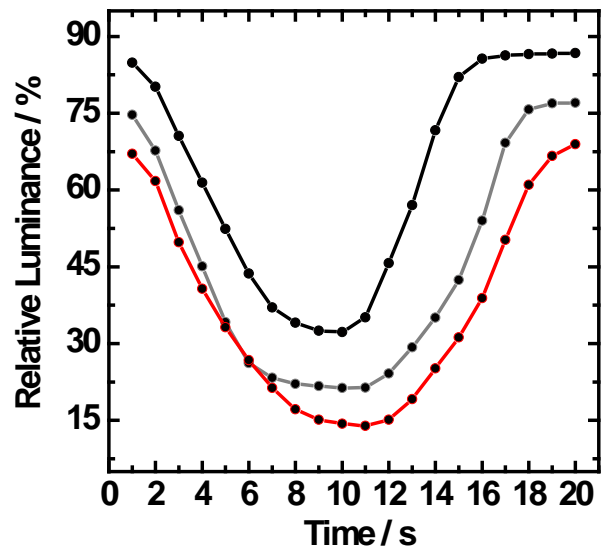

Figure 15. CIE 1931 relative luminance data vs. time for each of the $\mathrm{NiO} / \mathrm{NiOOH}$ films on FTO/glass. The films were prepared from the original as-deposited $\mathrm{NiO}$ films as indicated: $\mathrm{NiO}(10 \mathrm{~min})(\bullet \bullet), \mathrm{NiO}(15 \mathrm{~min})(\bullet \bullet)$ and $\mathrm{NiO}(2 \mathrm{O}$ 
$\min )(\bullet)$. Films were switched in aqueous $\mathrm{KOH}(0.1$ mol $\mathrm{dm}^{-3}$ ) between the 'bleached' and colored states by application of potential steps $(0.00 \mathrm{~V} \rightarrow+0.50 \mathrm{~V}$ for $10 \mathrm{~s}$ and $+0.50 \mathrm{~V} \rightarrow-0.20 \mathrm{~V}$ for $10 \mathrm{~s}$ ) vs. silver wire.

The CIELAB $L^{*} a^{*} b^{*}$ coordinates (Table 2 ) are a uniform color space defined by CIE in 1976 and offer a standard commonly used in the paint, plastic and textile industries. $L^{*}$ is the lightness variable of the sample, while $a^{*}$ and $b^{*}$ correspond to the two antagonistic chromatic processes (red-green and yellow-blue). In a $L^{*} a^{*} b^{*}$ chromatic diagram, $+a^{*}$ is the red direction, $-a^{*}$ is the green direction, $+b^{*}$ is the yellow direction, and $-b^{*}$ is the blue direction. The center $(0,0)$ of the chromaticity diagram is achromatic. As the $a^{*}$ and $b^{*}$ values increase, the saturation of the color increases. At the initial o.oo $\mathrm{V}$ applied potential, the 'bleached' state $\left(L^{*}=95, a^{*}=0, b^{*}=8\right)$ prepared from as-deposited $\mathrm{NiO}(10 \mathrm{~min})$ is close to the achromatic 'white point' $\left(L^{*}=100, a^{*}=0, b^{*}=0\right)$. For thicker films, there is a small decrease in the initial $L^{*}$ value, and an increase in $a^{*}$ and $b^{*}$ (Table 2). As the potential is stepped to $+0.50 \mathrm{~V}, L^{*}$ decreases and the saturation of the brown color increases, both $a^{*}$ and $b^{*}$ values becoming more positive (Table 2 ). With increase in film thickness, the brown coloration becomes more saturated as quantified by a decrease in $L^{*}$ when in its colored state and an increase in $a^{*}$ and $b^{*}$ (Table 2 ). Although it might be expected that a combination of positive $a^{*}$ and $b^{*}$ values would produce orange, in combination with low $L^{*}$ values, the films are perceived as deep brown.

\section{CONCLUSIONS}

Aerosol-assisted chemical vapor deposition (AACVD) has been used for the first time to prepare thin films of $\mathrm{NiO}$ on FTO-coated glass. Following transfer to aqueous $\mathrm{KOH}$ (o.1 mol dm $\mathrm{m}^{-3}$ ) and conditioning oxidative voltammetric cycling, the films show good electrochromic properties with reversible switching between transmissive light green and deep brown states. Using a calculation method based on the integration of experimental spectral power distributions derived from in situ visible region spectra over the CIE 1931 color-matching functions, the color stimuli of the NiO-based films, and the changes that take place on reversibly switching between the 'bleached' and colored forms have been calculated.

\section{ASSOCIATED CONTENT}

Supporting Information. EDS analysis, optical absorption spectra, an additional SEM image, and current-time transients are available. This material is available free of charge via the internet at http://pubs.acs.org.

\section{AUTHOR INFORMATION}

\section{Corresponding Author}

*E-mail: r.j.mortimer@lboro.ac.uk

\section{ACKNOWLEDGEMENT}

We thank the Loughborough University Materials Research School for the provision of a research studentship to MZS. AMT would like to acknowledge the funding received from the Government of Malaysia for his doctoral studies in the Department of Chemistry, Loughborough University, UK.

\section{REFERENCES}

(1) Monk, P. M. S.; Mortimer, R. J.; Rosseinsky, D. R. Electrochromism and Electrochromic Devices; Cambridge University Press: Cambridge, U.K., 2007.

(2) Mortimer, R. J. Annu. Rev. Mater. Res. 2011, 41, 241-268.

(3) Baetens, R.; Jelle, B. P.; Gustavsen, A. Sol. Energy Mater. Sol. Cells 2010, 94, 87-105.

(4) Byker, H. J. Gentex Corporation. Single-compartment, selferasing, solution-phase electrochromic devices, solution for use therein and uses thereof. 1990, US Patent 4,902,108.

(5) Niklasson, G. A.; Granqvist, C. G. J. Mater. Chem. 2007, 17, 127-156.

(6) Nagai, J.; McMeeking, G. D.; Saitoh, Y. Sol. Energy Mater. Sol. Cells 1999, 56, 309-319.

(7) Zelazowska, E.; Rysiakiewicz-Pasek, E. J. Non-Cryst. Solids 2008, 354, 4500-4505.

(8) Xu, Y. Z.; Qiu, M. Q.; Qiu, S. C.; Dai, J.; Cao, G. J.; He, H. H.; Wang, J. Y. Sol. Energy Mater. Sol. Cells 1997, 45, 105-113.

(9) Yueyan, S.; Zhiyang, Z.; Xiaoji, Y. Sol. Energy Mater. Sol. Cells 2002, 71, 51-59.

(10) Conell, R. S.; Corrigan, D. A.; Powell, B. R. Sol. Energy Mater. Sol. Cells 1992, 25, 301-313.

(11) Agrawal, A.; Habibi, H. R.; Agrawal, R. K.; Cronin, J. P.; Roberts, D. M.; Caron-Papowich, R.; Lampert, C. M. Thin Solid Films 1992, 221, 239-253.

(12) Scarminio, J.; Urbano, B.; Gardes, J.; Gorenstien, A. J. Mater. Sci. Letts. 1992, 11, 562-563.

(13) Carpenter, M. K.; Conell, R. S.; Corrigan, D. A. Sol. Energy Mater. 1987, 16, 333-346.

(14) Yuan, Y. F.; Xia, X. H.; Wu, J. B.; Chen, Y. B.; Yang, J. L.; Guo, S. Y. Electrochim. Acta 2011, 56, 1208-1212.

(15) Sharma, P. K.; Fantini, M. C. A.; Gorenstein, A. Solid State Ionics 1998, 113-115, 457-463.

(16) Dalavi, D. S.; Devan, R. S.; Patil, R. S.; Ma, Y-R.; Patil, P. S. Mater. Lett. 2013, 90, 6o-63.

(17) Dalavi, D. S.; Suryavanshi, M. J.; Patil, D. S.; Mali, S. S.; Moholkar, A. V.; Kalagi, S. S.; Vanalkar, S. A.; Kang, S. R.; Kim, J. H.; Patil, P. S. Appl. Surf. Sci. 2011, 257, 2647-2656.

(18) Zhang, E.; Tang, Y.; Zhang, Y.; Guo, C.; Yang, L. Mater. Res. Bull. 2009, 44, 1765-1770.

(19) Dalavi, D. S.; Devan, R. S.; Patil, R. S.; Ma, Y-R.; Kang, MG.; Kim, J-H.; Patil, P. S. J. Mater. Chem. A 2013, 1, 1035-1039.

(20) Patil, R. A.; Devan, R. S.; Lin, J-H.; Ma, Y-R.; Patil, P. S.; Liou, Y. Sol. Energy Mater. Sol. Cells 2013, 112, 91-96.

(21) Maruyama, T.; Arai, S. Sol. Energy Mater. Sol. Cells 1993, 30, 257-262.

(22) Hou, X.; Choy, K. L. Chem. Vap. Deposition 2006, 12, 583596.

(23) Choy, K. L. Progress in Materials Science 2003, 48, 57-170.

(24) Tahir, A. A.; Ehsan, M. A.; Mazhar, M.; Wijayantha, K. G. U.; Zeller, M.; Hunter, A. D. Chem. Mater. 2010, 22, 5084-5092.

(25) Dharmadasa, R.; Tahir, A. A.; Wijayantha, K. G. U. J. Am. Ceram. Soc. 2011, 94, 3540-3546.

(26) Tahir, A. A.; Wijayantha, K. G. U. J. Photochem. Photobiol., A 2010, 216, 119-125. 
(27) Bloor, L. G.; Manzi, J.; Binions, R.; Parkin, I. P.; Pugh, D.; Afonja, A.; Blackman, C. S.; Sathasivam, S.; Carmalt, C. J. Chem. Mater. 2012, 24, 2864-2871.

(28) Wyszecki, G.; Stiles, W. S. Color Science: Concepts and Methods, Quantitative Data and Formulae; $2^{\text {nd }}$ ed., John Wiley and Sons: New York, 1982.

(29) Mortimer, R. J.; Varley, T. S. Displays 2011, 32, 35-44.

(30) CIE Technical Report: Colorimetry, $3^{\text {rd }}$ ed.; Commission Internationale De l'Eclairage: Vienna, Austria, 2004.

(31) Kawar, R. K.; Chigare, P. S.; Patil, P. S. Appl. Surf. Sci. 2003, 206, 90-101.

(32) Patil, P. S.; Kadan, L. D. Appl. Surf. Sci. 2002, 199, 211-221.

(33) Garcia-Miquel, J. L,; Zhang, Q.; Allen, S. J.; Rougier, A.; Blyr, A.; Davies, H. O.; Jones, A. C.; Leedham, T. J.; Williams, P. A.; Impey, S. A. Thin Solid Films, 2003, 424, 165-170.

(34) Bouessay, I.; Rougier, A.; Beaudoin, B.; Leriche, J. B. Appl. Surf. Sci. 2002, 186, 490-495.
(35) Bouessay, I.; Rougier, A.; Tarascon, J.-M. J. Electrochem. Soc. 2004, 151, H145-H152.

(36) Bouessay, I.; Rougier, A.; Poizot, P.; Moscovici, J.; Michalowicz, A.; Tarascon, J.-M. Electrochim. Acta 2005, 50, 3737-3745.

(37) Huang, H.; Tian, J.; Zhang, W. K.; Gan, Y. P.; Tao, X. Y.; Xia, X. H.; Tu, J. P. Electrochim. Acta 2011, 56, 4281-4286.

(38) Lampert, C. M.; Omstead, T. R.; Yu, P. C. Sol. Energy Mater. 1986, 14, 161-174.

(39) Xia, X. H.; Tu, J. P.; Zhang, J.; Wang, X. L.; Zhang, W. K.; Huang, H. Sol. Energy Mater. Sol. Cells 2oo8, 92, 628-633.

(40) Arakaki, J.; Reyes, R.; Horn, M.; Estrada, W. Sol. Energy Mater. Sol. Cells 1995, 37, 33-41.

(41) Velevska, J.; Ristova, M. Sol. Energy Mater. Sol. Cells 2002, 73, 131-139. 

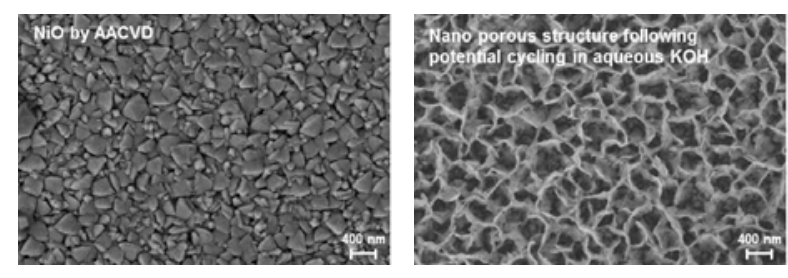

Insert Table of Contents artwork here 